\title{
The effect of the Cold War era on maps for public use in the Eastern Bloc countries: Tourist maps
}

\author{
László Zentai a,* , Gábor Gercsák ${ }^{\text {a }}$ \\ ${ }^{a}$ ELTE Eötvös Loránd University, Institute of Cartography and Geoinformatics, Budapest, Hungary, 1st Author - laszlo.zentai@elte.hu, 2nd \\ Author-gercsak@map.elte.hu \\ * Corresponding author
}

\begin{abstract}
Cartography of the Cold War era was very characteristic in the Eastern Bloc countries. The abnormal secrecy instructions forced by military cartographic authorities (following the Soviet advisors) influenced the making of all kinds of large- and medium-scale cartographic products for public use. Most of these maps were somehow distorted, although it was not easy to implement the technology of distortions developed by cartographers in the analogue map production era in the early 1960s. Tourist maps are expected to be created using topographic maps, but the access to classified topographic maps (both civilian and military) was limited for civilian users (even for civilian national mapping agencies, at least in the early years of the Cold War era). The tourist maps of this era were quite different from country to country in the Eastern Bloc, partly due to their cartographic traditions and to the relationships between the military and civilian cartography even influenced by the users’ demands.
\end{abstract}

Keywords: tourist maps, topographic maps, Cold War era, secrecy

\section{Introduction}

The main motivation of this paper is to draw not only the readers' attention to the cartographic products of the Cold War era, but also to encourage other researchers to uncover the hidden stories of this special time both in the former Eastern or Western Bloc countries. The Cold War era has different phases due to different 'coldness' of the Cold War era, all of them with different characteristics. Also, the political situation in the Eastern Bloc countries was not uniform either (not even in cartographic aspect). The differences were caused by the cartographic traditions and the diverse political situation of each country, although the Soviet Union pushed these countries to follow or rather simply to copy their actions.

Tourist maps were mostly published in large numbers as commercial products for everyday use. However, tourist maps are investigated thoroughly only relatively rarely by researchers in scientific papers.

\subsection{The Cold War era}

According to historians, the Cold War era started soon after World War II, when (just 75 years ago) Winston Churchill delivered his famous speech in Fulton declaring that the former alliance with the Soviet Union against the Axis powers was over and "From Stettin in the Baltic to Trieste in the Adriatic, an iron curtain has descended across the continent.”

The term 'Eastern Bloc' or 'Soviet Bloc' was used in the Western countries, but these Eastern and Central European countries named themselves as communist countries or people's democratic countries (mainly in the 1950s) and later as socialist countries. From now on, the paper is using this latter term.

The term 'Eastern Bloc' went into use as a shorthand for all of these countries, as it conveys the general Western sense of a non-Western socialist sphere in the period.
Yugoslavia, however, was never a member of the Warsaw Pact, which was the military alliance of socialist countries established in 1955. Thus, in military-political terms, Yugoslavia was not an Eastern Bloc country, while Albania left the Soviet military alliance in 1961 (Matless et al., 2008).

\subsection{The early tourist maps}

Some of the socialist countries published their first tourist maps before World War II, a few of them even at the end of the 19th century. This experience and tradition unquestionably influenced the publishing of their tourist maps in the Cold War era. Due to the lack of systematic research on tourist maps it is not easy to find information on the first tourist maps, but it looks obvious that the former Germany-Austria-influenced countries (East Germany, Poland, Czechoslovakia, Hungary) published their first tourist maps at that time. These countries were visited by early tourists at the end of 19th and at the beginning of 20th century, although the tourism of the time is not comparable to the recent form and extent of international tourism.

Thanks to the experience of publishing topographic maps (e.g. in former Austria-Hungary and in Germany), these early tourist maps are comparable in quality to the recent tourist maps. The tourist maps which were published before World War II were used and known fairly widely. This turned out to be a problem in these countries, because when the Soviet influence became complete at the end of 1940s, the Soviet Union urged the controlled countries to prohibit the use of the previously published maps. These quality maps were collected back and the residents were threatened by sanction if they did not surrender their home map copies. From that time on, the content of any maps issued for public use was strictly controlled and carefully checked by the military 
authorities, whose staff were educated by the Soviet advisors.

\subsection{Secrecy}

Secrecy of topographic maps was commonly used in the early times of systematic mapping. Most of the maps of military surveys of the Hapsburg Empire (later AustriaHungary) were classified. This was somehow evident due to the fact that these maps were only manuscripts, which were compiled and drawn by military cartographers and surveyors. One additional copy was also made/drawn, mostly for safety reason. As the emperor/empress financed the military surveys it was his/her and the military general staff's decision how these maps were used.

These military maps were the most detailed and most upto-date maps of the time. They really had a strategic role to help the military to defend their own area. Sometimes, in case of emergency (war) situations, smaller scale (socalled derived) maps were printed, most of which were also classified (Papp-Váry, 2010).

After the establishment of the Warsaw Pact in 1955, a new organ under common headquarters was founded, and this directly coordinated the activities of military cartographic services.

The 7th International Conference of the Geodetic Services of the Socialist Countries took place in Moscow in 1965. One of the most important decisions of this meeting declared that the topographic maps may no longer be used for civilian purposes. What is more, all kinds of civilian topographic maps were classified, which decision affected the other types of public maps, such as tourist maps or city maps. The only solution to avoid secrecy was to introduce distorted maps (see section 2) (Unverhau, 2009).

\subsection{The role of tourism}

The right to rest, leisure, and annual paid holidays was a feature of both the 1936 Soviet Constitution and the Universal Declaration of Human Rights of 1948 (Anderson et al, 2012). The chronologies of the Cold War and of international tourism cannot be understood without also taking the long-term socio-economic developments into account. The introduction of statutory paid leave in the interwar period and the switch to a fiveday working week in the 1950s and 1960s, for example, changed the patterns and concepts of consumption and leisure (Pedersen and Noack, 2019).

Socialist tourism was purposeful, and it perfected the socialist citizen by insisting on both the physically and the mentally restorative elements of tourism. However, tourist maps were not only made for domestic travellers, but for tourists of foreign countries too. Foreign tourists were coming mostly from the neighbouring socialist countries. However, visitors from Western countries was much more valuable for the host countries, because the local currencies were not convertible. That is why Western currencies were really welcomed by the national tourist agencies of socialist countries. As travelling to
Western countries was rather limited or nearly forbidden in most of the socialist countries in the Cold War era, the tourism agencies of the socialist countries had only limited chance to collect experiences on the touristic infrastructure of the Western countries. The main appeal of Eastern tourism for the Western tourists was definitely the cheapness and the exotics (including also some danger) of the beyond-the-iron-curtain mystery. Western interest in visiting Eastern Europe gave the socialist regimes an opportunity to showcase their societies, and to earn hard currency while doing so. However, Western tourists also presented the risk of espionage, and could be a negative influence on local populations by exposing them to foreign fashions and ideas. In other words, tourism in the Cold War was a field of competing cultural, economic, ideological, and security concerns (Anderson et al, 2012).

We practically cannot talk about incoming foreign tourism in the 1950s, when even the domestic tourism was vanishing especially when comparing it with the later decades. There were nearly no Western travellers (without home relatives) at that time, and the very few exceptions were definitely strictly monitored by the police or rather the counter-espionage. Former hotels and pensions were socialized and were used for the organised (labour union-based) resorting of workers.

However, the theory of peaceful coexistence inspired the socialist countries (both politically and economically) to invest into tourism after the end of 1950s. For example, in Hungary, the official statistics started to include data on tourism such as incoming and outgoing, foreign and domestic, accommodation usage (Probáld, 2018).

1967 was the International Year of Tourism, and the socialist countries also joined this initiative although the slogan was: Tourism is the road to peace.

\begin{tabular}{|l|r|}
\hline Country & Tourist arrivals \\
\hline Bulgaria & 5,120 \\
\hline Czechoslovakia & 3,983 \\
\hline East Germany & 15,962 \\
\hline Hungary & 9,847 \\
\hline Poland & 7,200 \\
\hline Romania & 6,034 \\
\hline USSR & 5,178 \\
\hline Yugoslavia & 5,966 \\
\hline
\end{tabular}

Table 1. International tourist arrivals in 1979 (in thousands) (World Tourism, 1981).

The touristic potential of the socialist countries was also different. The southern socialist countries (Romania, Bulgaria, and Yugoslavia) offered their seashore resorts, which were popular destinations for visitors from other socialist countries, but these countries also specifically addressed a Western European clientele in the new market for package holidays. According to statistics (Table 1), East Germany was the most popular touristic destination amongst socialistic countries in 1979. This is rather misleading because it includes also the daily visitors from West Berlin to East Berlin. In reality, 
Hungary and Yugoslavia were the most popular destinations for tourists at that time. Yugoslavia's success with international tourism also inspired the tourism sectors in Bulgaria and Romania in the next decades (Pedersen and Noack, 2019).

\section{Distortions}

The first civilian maps of cities and towns issued in socialist countries in the second half of the 20th century were developed at $1: 20,000$ to $1: 30,000$, without the scale explicitly stated on the actual map. A similar reduction of content was used on tourist and official maps (Konopska and Krukowski, 2018).

Research into maps from the 1950s shows that although they, in particular city plans, exhibited deficient content, these maps did not show any significant geometric distortions.

In the Soviet Union, all maps with a scale larger than $1: 1$ million were classified, but they even increased the limit to $1: 2.5$ million scale in 1966. Even the geographical maps of this scale were distorted in Soviet atlases, but the Western publishers and map users realized this trick, which was revealed in the Western countries.

The Soviet Union demanded the total separation of civilian and military map production and map use at the cartographic conference of the socialist countries in 1966. Socialist countries tried different solutions to meet the Soviet requirement: leave certain map objects and remove the graticule. This was a demand for larger-scale civilian maps in all socialist countries. East Germany was the first socialist country which produced such a special, open use civilian map series in $1: 200,000$ scale in 1966. The conference of the civilian national mapping agencies of socialist countries in 1968 asked East Germany to share its experiences. (When Hungary reproduced the methods of distortions and tried to publish a similar map series, the Hungarian military authorities were not satisfied with the result. They gave permission for publication only after an increased level of distortions). It is also important to remember that one of the most respected cartographic authorities of this time, the Hungarian Sándor Radó (who was allowed to leave the Soviet Union in 1955 after a decade of imprisonment) regularly referred to Lenin, the main ideologist of communism. Radó stated that he and Lenin had met in Moscow, during the 3rd Congress of the Communist International in 1921, when Lenin explained that the struggle against imperialism includes special forms of cartographic representation (Radó, 1974).

The distortions were completed on the state topographic maps using photographic methods. The films of the halved topographic maps in the scale of $1: 100,000$ were assembled through image transformation. This method distorted both the angles and distances, which made these maps not suitable for precise terrain navigation. Such method was also implemented on tourist maps, which had to be based on the enlarged version of the distorted state topographic maps. The tourist maps were even more inaccurate (Konopska and Krukowski, 2018).
The border areas to Western countries were the most sensitive territories in East Germany, Czechoslovakia and Hungary. In most cases, the countries chose an easy solution: delete these areas (and a relatively narrow zone along and inside the border) on the tourist maps.

\section{Situation of tourist maps by countries}

The publication of tourist maps was different from country to country. Their practice was based on the cartographic traditions (the first tourist maps were published even before World War I in some of these countries), on the need of domestic market (hiking activities) and the potentially interesting areas for tourism. In some of the socialist countries, where ski sport was also practiced, even winter versions of tourist maps were published (Czechoslovakia, Poland, East Germany).

\subsection{East Germany}

Tourism earned importance in Germany in the second third of the 19th century due to the development of railroad network, the organized package tours or company trips and also the famous Baedeker travel guides.

East Germany was established on the basis of the Soviet occupation zone in 1949, while West Germany was reorganized and gained independence from its occupiers (1945-1949).

Some smaller publishers issued few tourist maps soon after WW II (e.g. Sachsenverlag: Die Gute Wanderkarte series in 1951, Kurt Schaffmann's maps on Saxon Switzerland). Sachsenverlag Dresden began to issue hiking maps in 1948, which initially covered the closer and wider area of Dresden and were given the series name Die Gute Wandkarte (The Good Hiking Map). As early as 1951, the series was taken over by the VEB Bibliographisches Institut Leipzig and considerably expanded: the publication focus was on Saxony, Thuringia and the Harz Mountains. Up to 1960, a total of 66 different tourist maps were issued (the most frequently used scale was $1: 40,000$, but maps at $1: 30,000$ and $1: 50,000$ scales were also produced). The cartographic processing was carried out by various publishers in the series at that time and even the image of the cover pages was not uniform. The Bibliographisches Institut was closed in 1960. The hiking maps were handed over to VEB Landkartenverlag Berlin, which initially continued the series in part, but soon integrated it into its own publishing programme, dispensing with the concise green and white layout and the series name. Maps showing the border regions to West Germany were removed from the programme. The last maps of the series were published in 1967.

The VEB Landkartenverlag Berlin emerged from the Landkartenverlag Kurt Schaffmann after its owner had left the Eastern part of Berlin in 1953 and the publisher was then transferred to public ownership. The first hiking and winter sport maps covered the area of Brandenburg, Mecklenburg and Thuringia. 
When the publishing system was reorganized in 1964, only three publishers were entitled to issue maps for public use:

- VEB Hermann Haack GeographischKartographische Anstalt Gotha/Leipzig: responsible for general geographic and thematic atlases, various school cartographic products as well as geographic and cartographic books and magazines;

- VEB Räthgloben-Verlag Leipzig (used this name after 1972): globes;

- VEB Landkartenverlag Berlin: all kind of tourist maps, guidebooks.

The era of systematically distorted maps started in 1966 and affected the rest of the Cold War era. All tourist maps were routinely manipulated to decrease their accuracy from then on. The Dresden tourist map (with Saxon Switzerland) was published at a scale of $1: 100,000$ as the first sheet of the newly created tourist map series at the end of 1967. Even in the publishing house it was clear that the new (distorted and over-generalized) tourist maps were only to be regarded as insufficient orientation aids for hikers, especially outside of localities due to poor representation.

The newly founded VEB Tourist Verlag became the leading publisher of tourist maps and guidebooks since 1977. This publisher also exported and imported similar products of the other socialist countries (Noack, 2018).

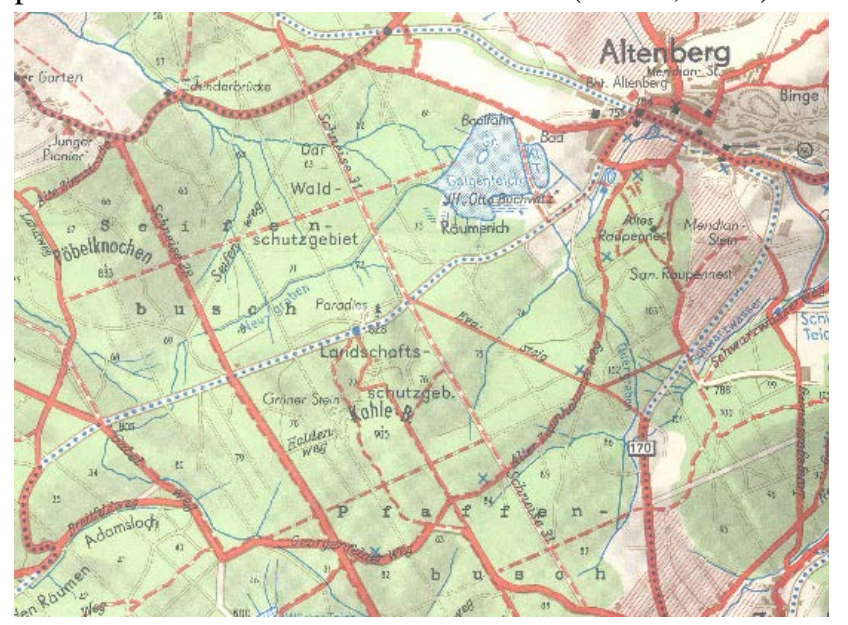

Figure 1. Tourist map of the Ost Erzgebirge (Eastern Ore Mountains), 1 : 30,000, 1964. Published by VEB Landkarten Verlag.

\subsection{Poland}

Recreation areas in Poland were designated in a national plan in 1963. The number of important recreation areas was indicated at 117, which covered circa 41 thousand $\mathrm{km}^{2}$, which is around $13 \%$ of the total country area. Their distribution followed the zones of natural landscapes spreading within Poland along parallels. Almost the whole coast of the Baltic Sea constitutes a narrow lowland zone, south of which is the zone of postglacial lakes. The seashore is very attractive since there are mostly sandy beaches with dunes. The Tatra Mountains in the south is also an important touristic destination (Widawski and Wyrzykowski, 2017).

The first Polish tourist map (Tatra Mountains) was published in the beginning of the 20th century. The tourist map of another important Polish touristic destination, the Karkonosze/Krkonoše was also published in the interwar period. The hiking started to develop and became more and more popular in the 1950s, when the hiking trail network meshed the touristic areas of the country (Janczewicz and Borowicz, 2017).

In 1949, mapping in Poland was reorganised with military mapping becoming the responsibility of the General Staff of the Polish Army and civilian mapping being undertaken by the Główny Urząd Geodezji i Kartografii (Head Office of Geodesy and Cartography). The Polish cartographic publishing house (Państwowe Przedsiębiorstwo Wydawnictw Kartograficznych, Warszawa-Wrocław [PPWK]) was established in 1951 and became the only institute allowed to publish map for civilians (Collier et al, 1996).

Like in other socialist countries, topographic maps were only occasionally mentioned in scientific papers. Particular attention was given to tourist cartography in the 1970s and 1980s, when the scientific conferences focused on issues related to the unification of cartographic symbols, including methods of content presentation and importance of cartography in the development of tourism (Janczewicz and Borowicz, 2017).

In the field of cartography, the 1970s brought only minor changes to the content of maps. Geometric deformations on particular maps were so large that additional information or greater detail could not raise the value of a map as a cartographic product. 1981 was the year of political changes, which removed the obligation to alter maps. Yet with no access to geographically accurate source materials, map quality had no possibility of improving (Figure 2).

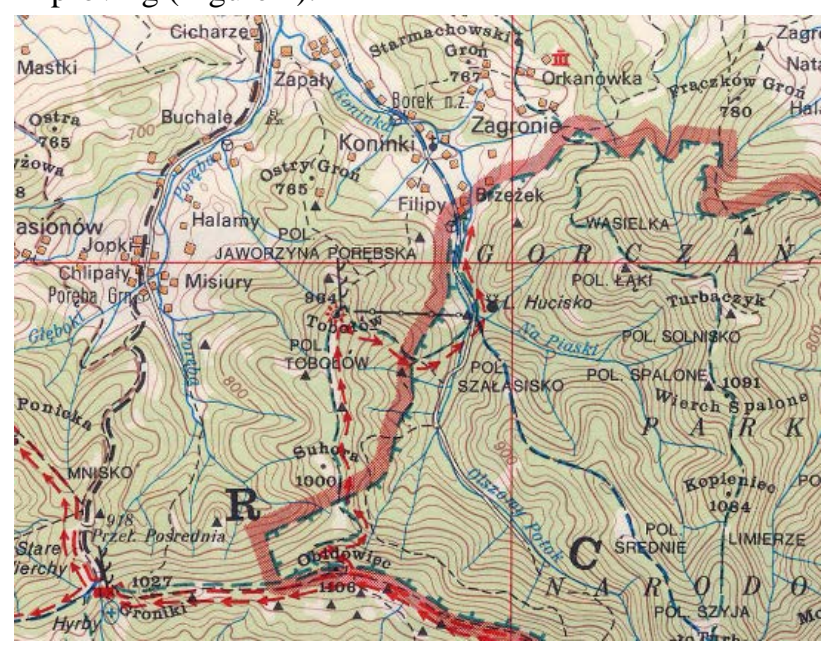

Figure 2. Tourist map of Beskid Makowski (Maków Beskids), $1: 75,000,1983$. Published by PPWK. 


\subsection{Czechoslovakia}

In the Czech environment, tourism began to develop with organized trips of companies or individuals in the first half of the 19th century. It played an important role in the last phase of the national revival, especially in the educated classes. The official history of Czech tourism began in 1888, when the Club of Czech Tourists was founded. The main activities of the club included the construction of tourist cottages, lookout towers, the modification and marking of tourist routes, the creation of tourist maps and other facilities for the public.

The first tourist guidebooks were published at the end of the 19th century. Tourist guides were usually supplemented with maps and sketches of recommended tourist routes. Several private publishing houses were involved in the creation of tourist maps. Tourist maps were published at a scale of $1: 75,000$ in the $1920 \mathrm{~s}$. The topographic basis consisted of the maps of the 3rd Military Survey. Finally, a total of 59 map sheets were available in German-Czech version in 1942 (only a few percent of the Protectorate of Bohemia and Moravia remained unmapped with tourist maps).

More than 40,000 active tourists were in the country before WW II, which meant a good market for tourist maps at that time.

Close cooperation between the renewed Club of Czechoslovak Tourists and Vojenský Zeměpisný Ústav (Military Geographical Institute), Prague, was renewed nearly immediately after WW II. The result was the publication of special maps at $1: 75,000$ with reprint of tourist information, uniformly for the entire territory of Czechoslovakia during the years 1945-1948. This period is sometimes referred to as the "golden age of tourist maps". In addition to the already mentioned publishers, Orbis and some other publishing companies began to publish tourist maps, but the sovietisation process soon ended these golden years.

New institutions were formed in 1954: the Central Administration of Geodesy and Cartography (ÚSGK) and the Slovak Administration of Geodesy and Cartography with territorial competence for Slovakia. This brought with it, on the one hand, the abolition of all civilian publishing houses that dealt with mapping, and, on the other hand, the monopolization of the publication of not only maps for schools and the public, but also maps for tourism.

ÚSGK got the permission of further use of $1: 75,000$ scale maps of the 3rd Military Survey as topographic base for civilian use, which led to a new set of tourist maps at a scale of $1: 100,000$, though their use was limited with the considerable generalization of content. In 1956, the first tourist map from this collection was issued: Krkonoše Mountains, $1: 100,000$, shortly afterwards, a tourist map of the High Tatras was published at the same scale. Between 1956 and 1968, a large part of the state territory was published in this series of tourist maps. At the Western state border, the Czech border areas adjacent to West Germany and Austria were not allowed to be displayed, but these restrictions were partly lifted off after the 1970s.

Kartografie Praha (since 1982 GKP Praha) released a new $1: 100,000$ scale tourist map series after 1968 to correspond to the existing regulations (few areas were published in larger scale). Extraordinary difficulties arose in the joint editions of tourist maps on the borders with East Germany and Poland (Figure 3), because their geodetic services, which were also obliged to perform topographic deformations according to their own regulations, used a different method of transformation (Mikšovský, 2014).
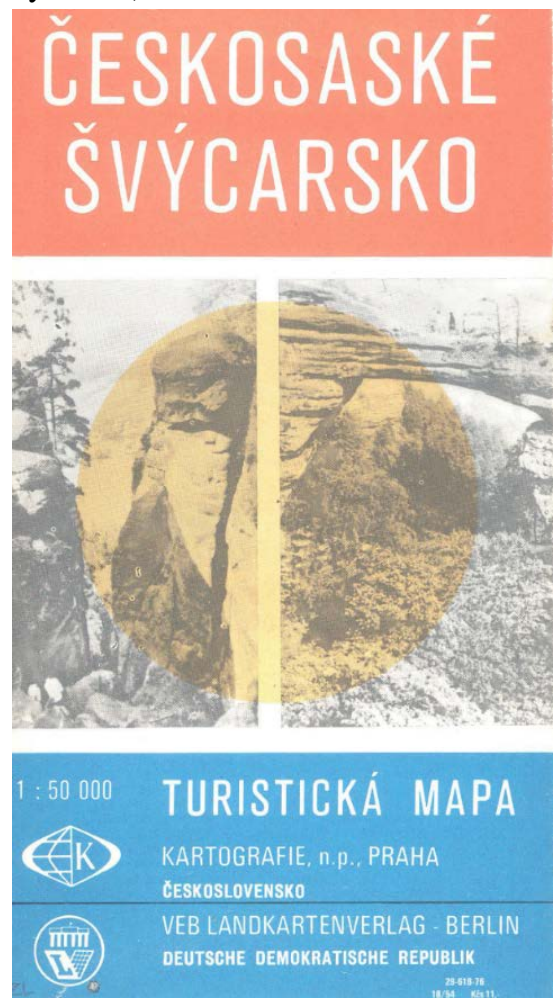

Figure 3. The title page of the tourist map of Českosaské Švýcarsko (Bohemian Switzerland), $1: 50,000,1974$. Joint publication of Kartografie Praha and VEB Landerkartenverlag Berlin.

\subsection{Hungary}

The first tourist map was published at the end of the 19th century (High Tatras, which was part of the Hungarian Kingdom until the end of WW I). Several other tourist maps were released before WW I, but all of these maps were published as part of tourist guidebooks. Between the two World Wars the State (Military) Mapping Institute published high-quality $1: 50,000$ scale tourist maps with 10-metre contour intervals.

A new civilian map publishing institute was formed, the Kartográfiai Vállalat (Cartographia) at the end of 1954 to supply the civilian market with tourist maps, city maps and all kinds of maps for educational use. They published their first tourist maps in 1956. In the early years, only hill shading was used for relief representation and also most of the linear man-made features (roads, railways) were slightly distorted and were represented as polygons based on the instructions of the military authorities 
(Figure 4). Even the scale of these early tourist maps were not indicated, only a scale bar was shown; after calculation the scale was not even a round number, which would be logical. Contour lines with 50 -metre contour interval appeared on the map, the lines of man-made features became curved lines in the next years, but the scale number was not indicated. The civilian users of these maps, the tourists did not appreciate the small animal and tree figures, hikers on the map, which helped the editors to hide sensitive features such as military objects. The scale number was indicated on the newly published maps after 1963, although showing it on the title page of the map was not allowed until the middle of the 1980s. Military authorities checked all maps before publishing, but sometimes Cartographia editors did not receive clear instructions from above. They said that maps were too precise, so their publication was not allowed unless the map content was revised.

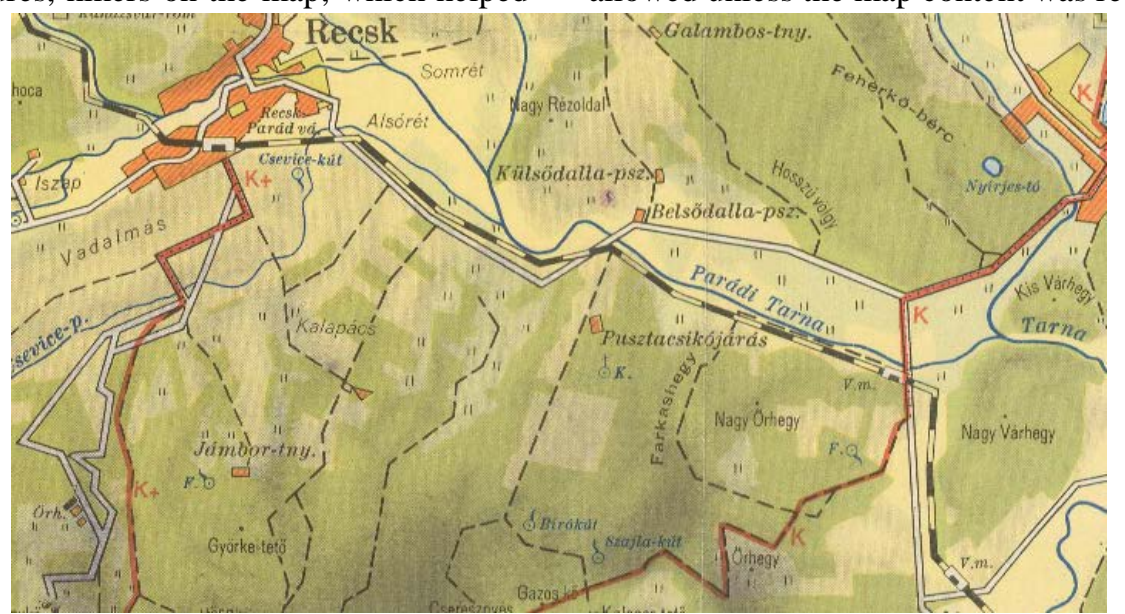

Figure 4. Tourist map of the Mátra Mountains, 1 : 50,000, 1956. Published by Cartographia.

There were also peculiar unpublished instructions probably given by the military authorities (similar regulations were applied also in Czechoslovakia and probably in the other socialist countries as well) (PappVáry, 2005; Mikšovský, 2014):

- the size of the mapped area was limited (not larger than $1,000 \mathrm{~km}^{2}$ ); larger mountains (Bakony, Bükk, Zemplén) were published on two sheets, but in different scales, and the two pieces regularly were not fit to each other (sensitive areas were covered by insets);

- the equidistance of the maps was also regulated, when Cartographia wanted to publish the tourist map of Lake Balaton in larger scale $(1: 40,000)$. However, they were not allowed to use smaller contour interval, so - to point out the meaninglessness of the instructions Cartographia published the maps with auxiliary contour lines on all parts of the map and all auxiliary contour lines were continuously drawn.

In practice, all mountains were mapped and published on tourist maps. As a large part of Hungary is the Great Hungarian Plain without hiking routes, these maps covered only a relatively small part of the country; some water sport maps were also published on the main rivers (Danube and Tisza) and on Lake Balaton. The hiking route network was later (since the 1980s) extended to plain areas and now there are tourist guide maps covering these areas (Rátóti, 1989).

\subsection{Romania}

In the interwar period, Romania experienced a particular development of tourism of any kind. Following the model of Western countries, tourism enthusiasts felt the need to form associations to represent their interests and passions. In the interwar period numerous cottages, facilities and paths were built, but only few of them remained in use today.

Maps were completely missing at that time, the only ones that were used being a series of sketches made by some geographers or engineers (a tourist map of Sinaia with surroundings was published in 1903). Six maps were published by the Cartographic Institute Unirea Brașov between 1930 and 1940 (Olariu, 2012).

After WW II, there were very few tourist map publications until 1974, when a Munții Noștri (Our Mountains) series was issued by the Sport-Turism. Maps of 51 areas were published till 1990. Actually, the Muntii Noștri series was a set of pocket tourist guidebooks with a supplemented relatively small-scale map (Figure 5).

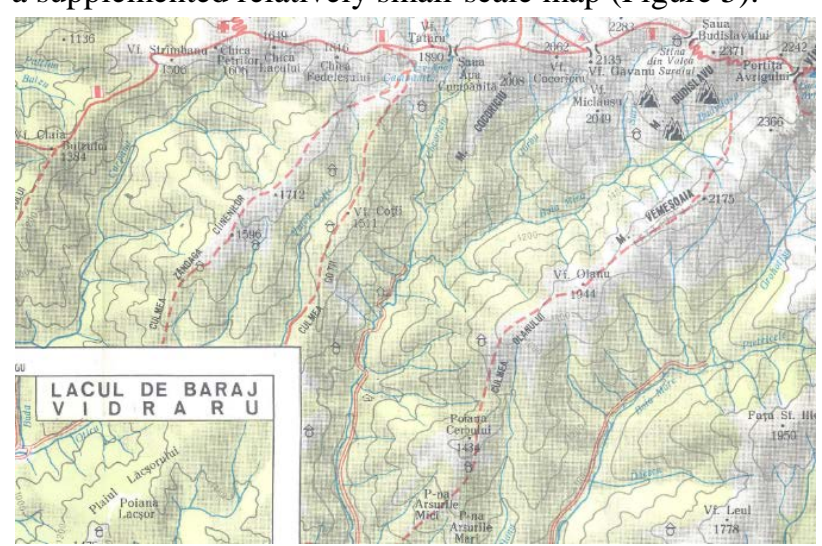

Figure 5. The map supplement of the first volume of the Muntii Nostri series (Făgăras), $\sim 1: 75,000,1974$. 


\subsection{Yugoslavia}

Between WW I and WW II, besides hand-drawn ridge maps of Slovenian Alps, there were some school maps and atlases as well as some special thematic maps published.

The break with the Soviet Union in the beginning of the Cold War era was a severe shock for the Yugoslav communists. Early in 1949, the Soviet Union and its East European allies excluded Yugoslavia from the founding of the Council for Mutual Economic Assistance (known as Comecon) and set up a hermetically tight trade blockade and soon caused a long-lasting war psychosis. The unusual historical constellation that evolved in the early phase of the Cold War offered Tito new foreign policy options. The death of Stalin in 1953, however, offered a chance to mend Soviet-Yugoslav relations, but Tito was also to steer his independent course successfully.

After WW II, besides individual mountain or municipality maps, there were few civilian cartographic institutions, like Učila Zagreb (mountain map Medvednica above Zagreb from 1957, 1:50,000), Geokarta Belgrade (mostly city maps, airline maps), and Geodetski zavod Slovenije and Institute for Geodesy and Photogrammetry, both from Ljubljana. Their first modern mountain (tourist) map at $1: 50,000$ (Julian Alps) was the basis for following mountain maps. There were some restrictions about the scale, contour interval, content, but no evidence was ever found that the content was geometrically distorted. Probably, Yugoslavia did not follow the strict Soviet instructions on map distortions at that time (Petrovič, 2001).

The tourist resort business did not start in Yugoslavia until the 1950s, which was much later than in Spain and Italy. In 1966, the government recognized tourism to be a motor for development and social change and therefore designated it as a priority for investment. Tourism became a recognized discipline for research and study within economics. In 1967, Yugoslavia abolished visa requirements for all states worldwide (Calic, 2019).

Finding any scientific papers or references on the tourist maps of Yugoslavia is difficult. Several firms were formed after the dissolution of Yugoslavia, but probably the policy concerning public maps - like in other socialist countries in the Cold War era - was only partially used.

\subsection{Bulgaria}

Nearly $40 \%$ of Bulgaria's territory is deemed suitable for tourism with its many beaches, mineral springs, and winter sport areas. Tourism has been an important sector of the Bulgarian economy since the establishment of the Bulgarian Hikers' Association in the 1890s, shortly after Bulgaria's liberation from Ottoman rule. During the 1930s, 15,000 tourists visited Bulgaria's seaside resorts annually. The first national park, Mount Vitosha, which is near the capital of Sofia, was also established in the 1930s.
Tourism development in Bulgaria gained momentum after the WW II (Balkantourist was founded in 1948). Within the Comecon (Council for Mutual Economic Assistance, 1949-1991), which was the equivalent of the European Economic Community for the socialist countries, Bulgaria was specialising in tourism. In this regard during the 1950s and 1960s large sea-side mass tourism resorts were constructed. The mountain resorts of "Pamporovo" (in the Rhodopes) and "Borovets" (in Rila) were the flagships of winter skiing. The predominant market segments were the Soviet Union and the countries from the Eastern Bloc in the 1950s. In 1964, visa requirements were eliminated for visitors from the socialist countries. Thereafter, Bulgaria attracted more foreign tourists than any other socialist country (Ivanov and Dimitriva, 2010).

Unfortunately, the authors could not find any papers on Bulgarian tourist maps, not even with the help of Bulgarian colleagues. Checking large online library catalogues showed they have Bulgarian tourist map records from 1935 (Rila Mountains, $1: 75,000$ ) in the Library of Congress (https://catalog.loc.gov/), but only bibliographic data are available and not the scanned maps.

\subsection{Soviet Union}

It is still very difficult to get information on Soviet Union's map production in the Cold War era or even after the 1917 Soviet Revolution. Since even the small-scale geographic maps were distorted, it is not surprising that tourist maps and maps of the administrative units (such as regional and district maps) were usually compiled at 1: 600,000 scale. They showed only the most general data for the main towns, villages, and roads. After all, the tourist maps published in this era in the Soviet Union looked like sketches (they even used the self-critical term schema) instead of real maps. However, even access to these maps was not simple, although in some cases it was vital, for example for higher mountains (Caucasus, Pamir Mountains) (Figure 6).

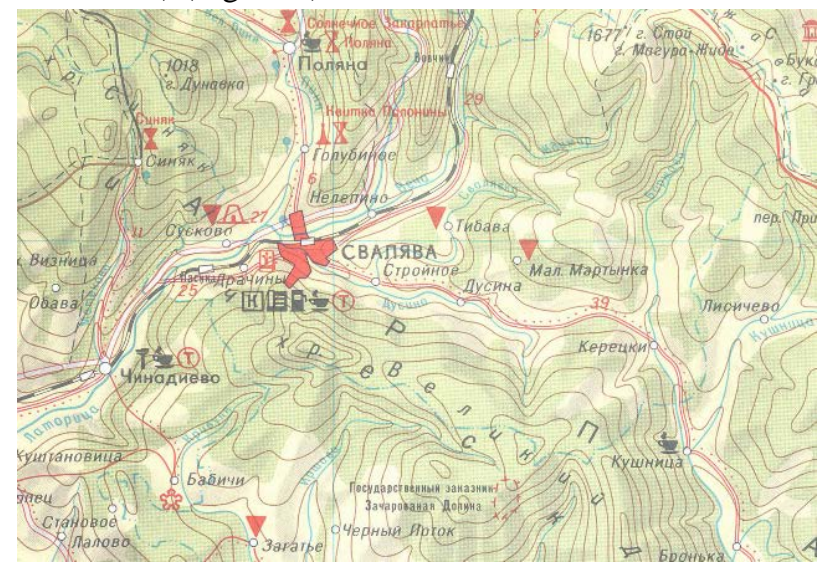

Figure 6. A very late Cold War era tourist map, Закарпатская область (Zakarpattia District), 1 : 300,000, 1986. (Unusually detailed, but this is not really a touristic map scale.)

Limitations on Soviet cartography were relaxed only after the perestroika. In 1989, the Military Topographical Service of the General Staff and the Chief Administration 
of Geodesy and Cartography began to publish maps for sale to ordinary consumers. The maps had scales of $1: 200,000$ and smaller and were based on topographic maps stripped of military and other information deemed confidential (Postnikov, 2002).

\section{Conclusions}

The main motivation of this paper was to encourage the former socialist countries to research on tourist maps and to help understand how the Cold War era of the history and the mistrust between the West and East influenced the cartographic production, including even the tourist maps. The Soviet Union did not consider the cartographic tradition and need of allied countries; the maps of these four decades are prominent evidences of the abnormal influence of politics on everyday life. This is justified by the distortion of tourist maps and city maps, which products were perhaps the largest volume of civilian maps in use at this time.

Looking at this era from the side of map users and map publishers (in practice, they were only state civilian institutes or companies) it is obvious that these publishers tried to meet user needs, but the military-political regulations of the time did not support their effort.

Cartographers in this part of the world have to document this era through maps too that explain the pointless regulations of distorting the geometry of maps and the manipulations of map content, which policy lived for several decades after the mid-20th century.

\section{References}

Anderson, J., Hirt, S., Slaev, A. (2012). Planning in Market Conditions: The Performance of Bulgarian Tourism Planning During Post-Socialist Transformation. JOURNAL OF ARCHITECTURAL AND PLANNING RESEARCH, 29:4, pp. 318-334.

Calic, M-J. (2019). A History of Yugoslavia. Purdue University Press, ISBN: 978-1-55753-838-3

Collier, P., Fontana, D., Pearson A. and Ryder, A. (1996). The State of Mapping in the Former Satellite Countries of Eastern Europe, THE CARTOGRAPHIC JOURNAL, 33:2, 131-139, DOI: 10.1179/caj.1996.33.2.131

Ivanov, S. H., Dimitriva, M. G. (2019). Tourism Management and Planning in Bulgaria, SSRN Electronic Journal, May, DOI: 10.2139/ssrn.1599611

Jancewicz K., Borowicz D. (2017). Tourist maps definition, types and contents, POLISH CARTOGRAPHICAL REVIEW. 49:1, pp. 27-41., DOI: 10.1515/pcr-2017-0003

Konopska, B., Krukowski, M. (2018). Image data paradox - on the impact of the development of imagebased remote sensing on the maps' content in the Eastern Bloc. The case of Poland. POLISH CARTOGRAPHICAL REVIEW, 50:4, pp. 211-222., DOI: 10.2478/pcr-2018-0016

Matless D., Oldfield, J., Swain, A. (2008). Geographically Touring the Eastern Bloc: British
Geography, Travel Cultures and the Cold War. TRANSACTIONS OF THE INSTITUTE OF BRITISH GEOGRAPHERS, Jul., 2008, New Series, Vol. 33, No. 3 (Jul., 2008), pp. 354-375. https://www.jstor.org/stable/30131223

Mikšovský, M. (2014). K historii vydávání turistických map. In. Pavel Hánek (ed.) $\mathrm{Z}$ dějin geodézie a kartografie, Praha: Národní technické muzeum, Rozpravy Národního technického muzea v Praze; ISBN 223 0035-9378, p. 325.

Noack, G. (2018). Die Entstehung und Herausgabe von touristischen Karten der DDR, PhD dissertation, Mathematisch-Naturwissenschaftlichen Fakultät der Universität Greifswald, https://epub.ub.unigreifswald.de/files/2326/Dissertation+Noack.pdf

Olariu, B. (2012). Hărțile turistice ale T.C.R. - Avântul turismului montan în România, http://geospatial.org/vechi/download/hartile-turistice-ale-tcr

Papp-Váry Á. (2005). Torzított turistatérképek Magyarországon. GEODÉZIA ÉS KARTOGRÁFIA, 57:11, pp. 18-23.

Papp-Váry Á. (2010). Két évtizede nem titkosak a térképek. GEODÉZIA ÉS KARTOGRÁFIA, 62:1, pp. 22-25.

Pedersen, S.B., Noack, C. (eds) (2019). Tourism and Travel during the Cold War. Negotiating Tourist Experiences across the Iron Curtain. Routledge, London and New York, ISBN: 978-0-367-19212-9

Petrovič, D. (2001). Mountain Cartography in Slovenia CARTOGRAPHICA, 38:1\&2, pp. 24-30.

Postnikov, A.V. (2002). Maps for Ordinary Consumers versus Maps for the Military: Double Standards of Map Accuracy in Soviet Cartography, 1917-1991, CARTOGRAPHY AND GEOGRAPHIC INFORMATION SCIENCE, 29:3, 243-260, DOI: 10.1559/152304002782008431

Probáld Á. (2018). A hazai turizmusstatisztika története (History of the Hungarian tourism statistics). STATISZTIKAI SZEMLE, 96:6, pp. 610-640., DOI: 10.20311/stat2018.06.hu0610

Radó, S. (1974). Dora reports. Autobiography; Berlin: Military Publishing House of the GDR.

Rátóti B. (1989). A Kartográfiai Vállalat turistatérképei. GEODÉZIA ÉS KARTOGRÁFIA, 41:3, pp. 195-200.

Unverhau, D. (ed) (2009). Geheimhaltung und Staatssicherheit. Zur Kartographie des Kalten Krieges Teilband 1: Beiträge und Anlagen - Teilband 2: Abbildungen, Münster, LIT Verlag

Widawski, K., Wyrzykowski, J. (eds) (2017). The Geography of Tourism of Central and Eastern European Countries (Second edition), Springer, ISBN 978-3-31942203-9, DOI 10.1007/978-3-319-42205-3

World Tourism Organisation: World Tourism 1979-1980 (1981). https://www.eunwto.org/doi/pdf/10.18111/unwtogad.1981.1.15l7gmm 025220756 